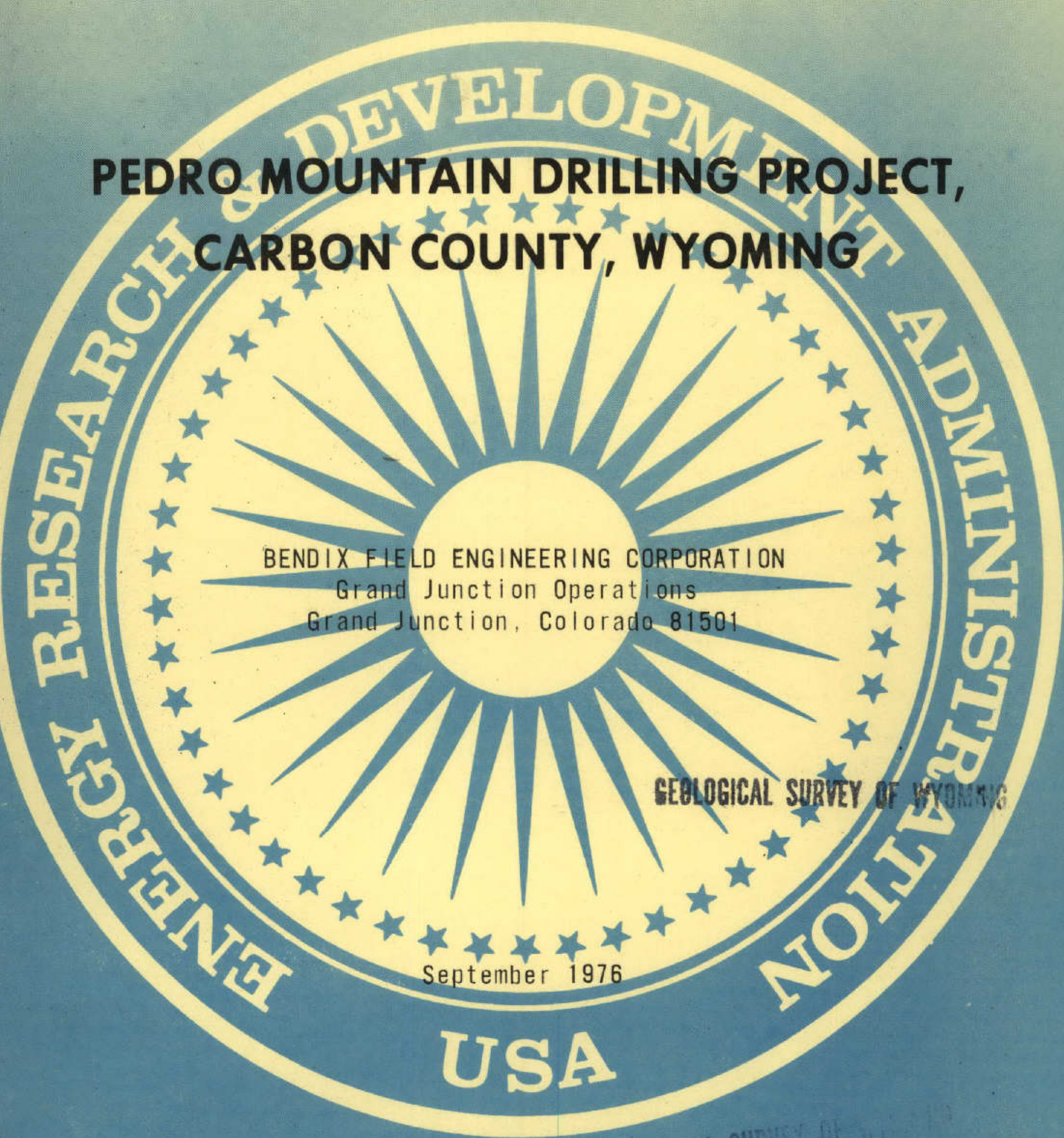




\section{LEGAL NOTICE}

This report was prepared as an account of work sponsored by the United States Government. Neither the United States nor the United States Energy Research and Development Administration, nor any of their employees, nor any of their contractors, subcontractors, or their employees, makes any warranty, express or implied, or assumes any legal liability or responsibility for the accuracy, completeness or usefulness of any information, apparatus, product or process disclosed, or represents that its use would not infringe privately owned rights. 


\title{
PEDRO MOUNTAIN DRILLING PROJECT, CARBON COUNTY, WYOMING
}

\author{
T. J. Price, M. C. Callihan, and R. G. Young \\ (Bendix Field Engineering Corporation) \\ J. S. Stuckless \\ (U.S. Geological Survey)
}

\section{BENDIX FIELD ENGINEERING CORPORATION \\ Grand Junction Operations \\ Grand Junction, Colorado 81501}

September 1976

PREPARED FOR THE U.S. ENERGY RESEARCH AND DEVELOPMENT ADMINISTRATION GRAND JUNCTION OFFICE

UNDER CONTRACT NO. E(05-1)-1664 

Summary . . . . . . . . . . . . . . . . . . . 1

Introduction . . . . . . . . . . . . . . . . . . . . 2

Location ..................... . . 2

Purpose ........................ 2

Previous work . . . . . . . . . . . . . . . 2

History . . . . . . . . . . . . . . 4 4

Acknowledgments . . . . . . . . . . . . . . . 4

Drflling ....................... 5

Pre-coring phase................... 5

Move in and setup ................... 5

Site preparation .............. 5

Spud-in and surface casing ............. 5

Coring phase ..................... 5

First-stage coring ................ 5

Second-stage corlng............. . 5

Third-stage coring ............. 7

Other considerations................ . . 7

Work Schedule... . . . . . . . . . . 7

Weather .................... 7

Water supply ................ . . 7

Geothermal study ............... 7

Completion .................... 8

Sumary of core lithology . . . . . . . . . . . . . . 8

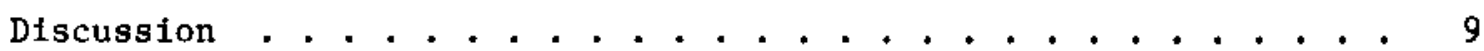

Geophyslcal logging . . . . . . . . . . . . . . . 10 
CONTENTS (continued)

Page

Evaluation of geophysical logs . . . . . . . . . . . . 11

KUT . . . . . . . . . . . . . . . . 11

Caliper . . . . . . . . . . . . . . . . . 12

Neutron-neutron ................. 12

Magnetic susceptibllity . . . . . . . . . . . . 12

Gamma-electric . . . . . . . . . . . . . 13

Geophysical instrument performance . . . . . . . . . 13

Conclusions . . . . . . . . . . . . . . . . . . . . 13

Appendix A. Additional drilling data . . . . . . . . . . . A-1 
Figure 1. Location map .................. 3

2. Photo of drill rig on location........... 6

Plate 1. Lithologic log of Pedro Mountain

No. 1 drill hole. . . . . . . . . . . . . . . In pocket

2. Birdwel1 directional survey ........... In pocket

3. Birdwe11 gamma-ray neutron $\log . . . . . . . .$. In pocket

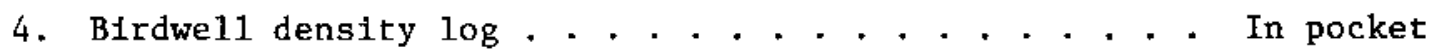

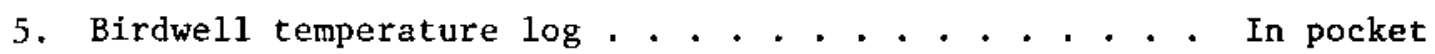

6. Birdwe11 three-dimensional velocity $\log . . . . .$. In pocket

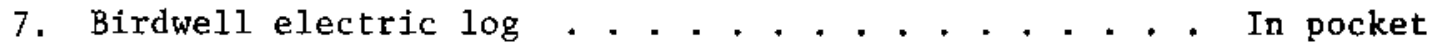

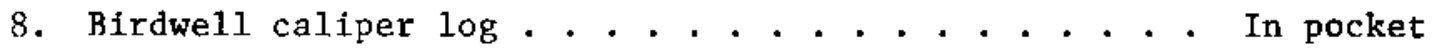

9. BFEC caliper, gross gamma, neutron-neutron, and magnetic susceptibility logs........... In pocket

10. BFEC spectral gamma (KUT) log . . . . . . . . . In pocket 



\section{SUMMARY}

The Pedro Mounta1n drilling project, which consisted of drilling a core hole to a depth of 2,197 feet in granite in Carbon County, Wyoming, was completed in May 1976. The major objective of this cooperative project between the U.S. Energy Research and Development Administration and the II.S. Geological Survey is furtherance of the evaluation of the Granite Mountains area as a potential source of the large uranium deposits in Tertiary sandstone in adjacent sedimentary basins.

The hole, with a planned depth of 2,500 or 3,000 ft, was drilled by Himes Drilling Company, the subcontractor, during the perlod from March 10 to May 7, 1976. Because of difficult drilling conditions, the coring was done in three stages - HQ to $75 \mathrm{ft}$, NQ to $1,974 \mathrm{ft}$, and $B Q$ to $2,197 \mathrm{ft}$. Total core recovery was excellent, averaging 94.4 percent.

It was hoped that the hole could be drilled entirely in granite but altered diabase was encountered just beneath the alluvium and was the dominant rock type in the upper $122 \mathrm{ft}$. From 122 to $141 \mathrm{ft}$ the hole penetrated pink to red granite. At $144 \mathrm{ft}$ there was a transition to lightpink to 1ight-gray granite, which persisted to $1,173 \mathrm{ft}$ where altered diabase was cut. The hole remained in the diabase to $1,566 \mathrm{ft}$ where it again penetrated granite, which was predominant to the bottom of the hole. Preliminary studies of the cores suggest that uranium leaching has occurred to tota1 depth.

Geophysical logging was preformed by four organizations: Birdwel1 Diviston, Seismograph Service Corporation; Bendix Field Engineering Corporation - Advanced Technology Division; U.S. Geological Survey - Water Resources Group; and U.S. Geologlcal Survey - Geophysical Group. Seventeen different logs were run in the hole and are now being studied. Preliminary indications are that the KUT (spectral-gamma) $\log$ is the most useful in evaluating holes of this type. 
INTRODUCTION

LOCATION

The Pedro Mountain No. 1 core hole (PM-I) is approximately 53 mfles

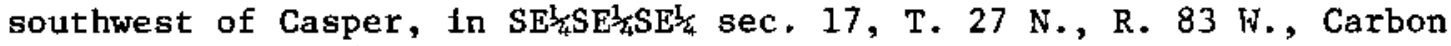
County, Wyoming (Fig. 1). Pedro Mountain is the name applied to the extreme eastern end of the Granite Mountains, a low range of hills composed primarily of grantte of Early Precambrian age.

The site is on public domain in the Medicine Bow Resource Area of the Rawlins District of the Bureau of Land Management (BLM). Grazing rights in the area are under lease to Wheatland Farms.

\section{PURPOSE}

This cooperative project berween the U.S. Energy Research and Development Administration (ERDA) and the U.S. Geological Survey (USGS) for the coring of granite in the Pedro Mountains is the outgrowth of an on-going USGS project: Uranium Source Rocks Studies -- Granitic Rocks. This project had concentratid its efforts in the Granite Mountains, Wyoming. The Pedro Mountains, an eastward extension of the Granite Mountains, are composed of Early Precambrian alkalic granite.

These Precambrian granitic rocks have been proposed as a source for uranium ore in the Crooks Gap, Gas Hills, Powder River Basin, and Shirley Basin uranium districts. Indirect evidence supporting this suggestion includes (1) proximity of the granite to the uranlum districts, (2) Indications that the granite was the source for the sedimentary rocks that form the hosts for the ore, and (3) uranium-lead isotopic data that demonstrate a uranfum loss from the granite of approximately $20 \mathrm{~g} /$ ton or 80 percent since Cretaceous time.

\section{PREVIOUS WORK}

Previous work in the Granite Mountains has included analyses of cores from two drill holes (GM-1 and GM-2) near Jeffrey City. These dri11 holes penetrated biotite alkalic granite, a partly assimflated metamorphic xenolith, and thin zones of albltized granite. Several surface samples of alkalic granite and silicified-epldottzed granite were also analyzed. There Is 1sotopic evidence for uranium mobility for each analyzed rock type. Most samples have lost uranium, but a few portions of the core have gained significant amounts of uranuim. Even the deepest samples $(1,326 \mathrm{ft}, 404.3 \mathrm{~m})$ taken from the assimilated xenolith exhtbit evidence of uranium loss.

Two distinct events, at the western end of the Granite Mountafns, have been identified from whole-rock $\mathrm{Rb}-\mathrm{Sr}$ and $\mathrm{U}-\mathrm{Pb}$ geochronology: (1) formation of metamorphic rocks about $2,900 \mathrm{~m} . \mathrm{y}$. ago and (2) intrusion of the granite about $2,600 \mathrm{~m} . y$. sgo. Scant data for rock-mineral geochronology suggest another event at approximately 1,400 to $1,800 \mathrm{~m} . \mathrm{y}$. ago, but consistent ages have been obtalned 
R.e3w.

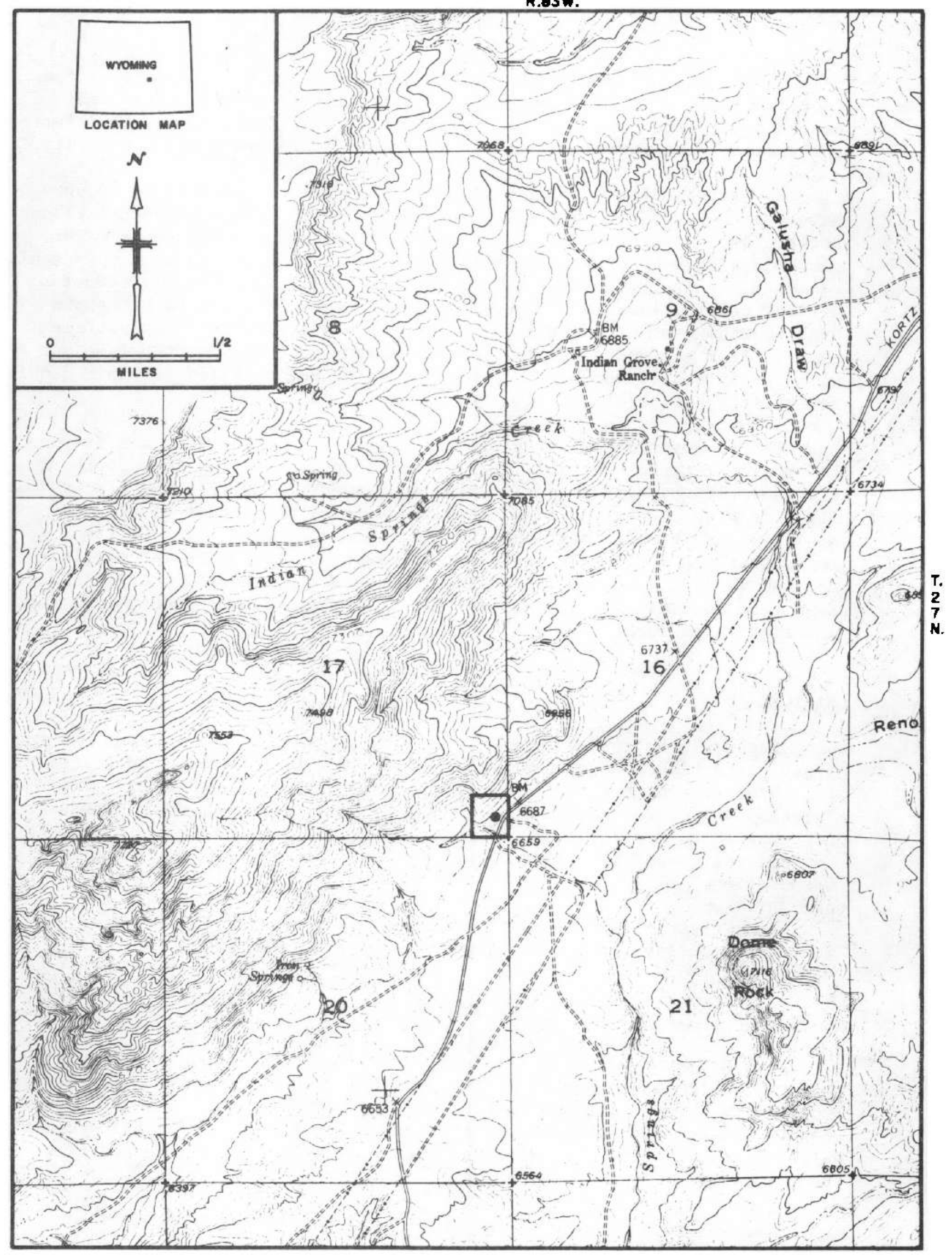

Figure 1. Location map, Pedro Mountain No. I drill hole. 
only at the eastern end of the Granite Mountains in the vicinity of the Pedro Mountains. These samples also have the largest percentage and amount of Cenozolc uranium loss. From this coincldence it may be inferred that Precambrian events influenced the apparent recent urantum mobility.

Several samples with widely varying thorium contents (1 to $70 \mathrm{ppm}$ ) have been analyzed in this study, but there is no well-defined relationship between percent uranfum loss and present-day thorium content. However, there is a strong correlation between original thorium and original uranium contents. As a consequence of this relationship and the nearly constant percent uranium loss, there seems to be a strong correlation between a high thorium content and a large amount of uranium loss. Many surface samples from the Pedro Mountains contain more than 100 ppm thorlum, but they were too intensely weathered to be useful for the detafled tsotopic studies to test the amount of uranium loss.

The cooperative drilling project in the Pedro Mountains was proposed to provide material suitable for investigating (1) the maximum deoth of uranium mobility, (2) the existence of an event 1,400 to $1,600 \mathrm{~m} \cdot \mathrm{y}$. ago and its effect on current uranium mobility, and (3) the amount of uranium mobility in a granfte with a high radioelement content. In addition, it was hoped that the drill hole would provide samples from which the original uranium distribution could be determined, and that the hole could be used as a test locality for calibration and interpretation of geophysical logs in crystalline rock.

\section{HISTORY}

Proposals to core as much as 3,000 ft of NQWL hole were sent out to prospective bidders on January 19, 1976. Bids were returned on February 10, 1976, and the contract was awarded to Himes Drilling Company of Grand Junction, Colorado, on March 5, 1976. Geophysical logging was conducted from May 10 to May 16, 1976, by U.S. Geological Survey, Bendix Field Engineering Corporation (BFEC), and Birdwell Division, Selsmograph Service Corporation.

Site cleanup and rehabilitation was completed and inspected as satisfactory by Bureau of Land Management personnel on May 24, 1976.

\section{ACKNOWLEDGMENTS}

The project geologist was John Stuckless, U.S. Geological Survey; and the project engineer was T. J. Price of BFEC. U.S. Geological Survey geologists Myron Smith and Norman Lewis and BFEC geologists Scott Hesee and Joseph Dunagan were present throughout the project. The BFEC logging effort was evaluated by Michae1 Callihan; all data were collected by Robert Young. 
One objective of this report is the description of the drilling procedures used in the Pedro Mountain project. The general procedures and problems 1nvolved are discussed below. Detalls such as bit size, mud pump pressure, casing type, hole deviation, and drilling mud characteristics are tabulated in Appendix A.

\section{PRE-CORING PHASE}

Move In and Setup

The rig left Grand Junction at 7:30 a.m., March 8, and arrived at the dril1 site at $11: 30 \mathrm{a} . \mathrm{m} .$, March 9. The drill setup was completed at noon, March 10. The rig is shown on location in Figure 2.

\section{Site Preparation}

Leveling of the drill site was unnecessary. Two earth-type mud pits, each $5 \mathrm{ft}$ wide, $12 \mathrm{ft}$ long, and $8 \mathrm{ft}$ deep, were dug with a backhoe.

Spud-In and Surface Casing

On March 10 at noon, the hole was spudded with a 6-3/4-in. tricone rock bit, drilling open-hole through the surface soil. At a depth of $11 \mathrm{ft}$, bed rock was reached and $11-1 / 2 \mathrm{ft}$ of $4-1 \mathrm{n}$. I.D. casing was set.

\section{CORING PHASE}

First-Stage Coring

HQ coring (2.5 in. core diameter) was started at $11 \mathrm{ft}$ in a closely fractured diabase, which caused frequent blocking of the core bit and resulted in some very short core runs. Because of the unstable nature of the formation, some of the side wall of the hole collapsed each time the core barrel was removed for bit change. This necessitated reaming the hole to the bottom with each new core bit, which commonly resulted in damage to the inner gauge of the bit. After an unsuccessful attempt was made to ream the hole with the 6-3/4-in. rock bit to enable 4-in. casing to be set through the highly fractured formation, the hole was cemented and rereamed to the original depth. This method worked satisfactorily and enabled the HQ coring to proceed to a depth of $75 \mathrm{ft}$, where the rock was less fractured; the HQ drill rod was then set as casing ( 3.065 in. I.D.) to a depth of $75 \mathrm{ft}$.

\section{Second-Stage Coring}

After the HQ casing was set, the core size was reduced to NQ (1.875 in.) and coring continued. Some drilling fluid was lost between 75 and $190 \mathrm{ft}$ 


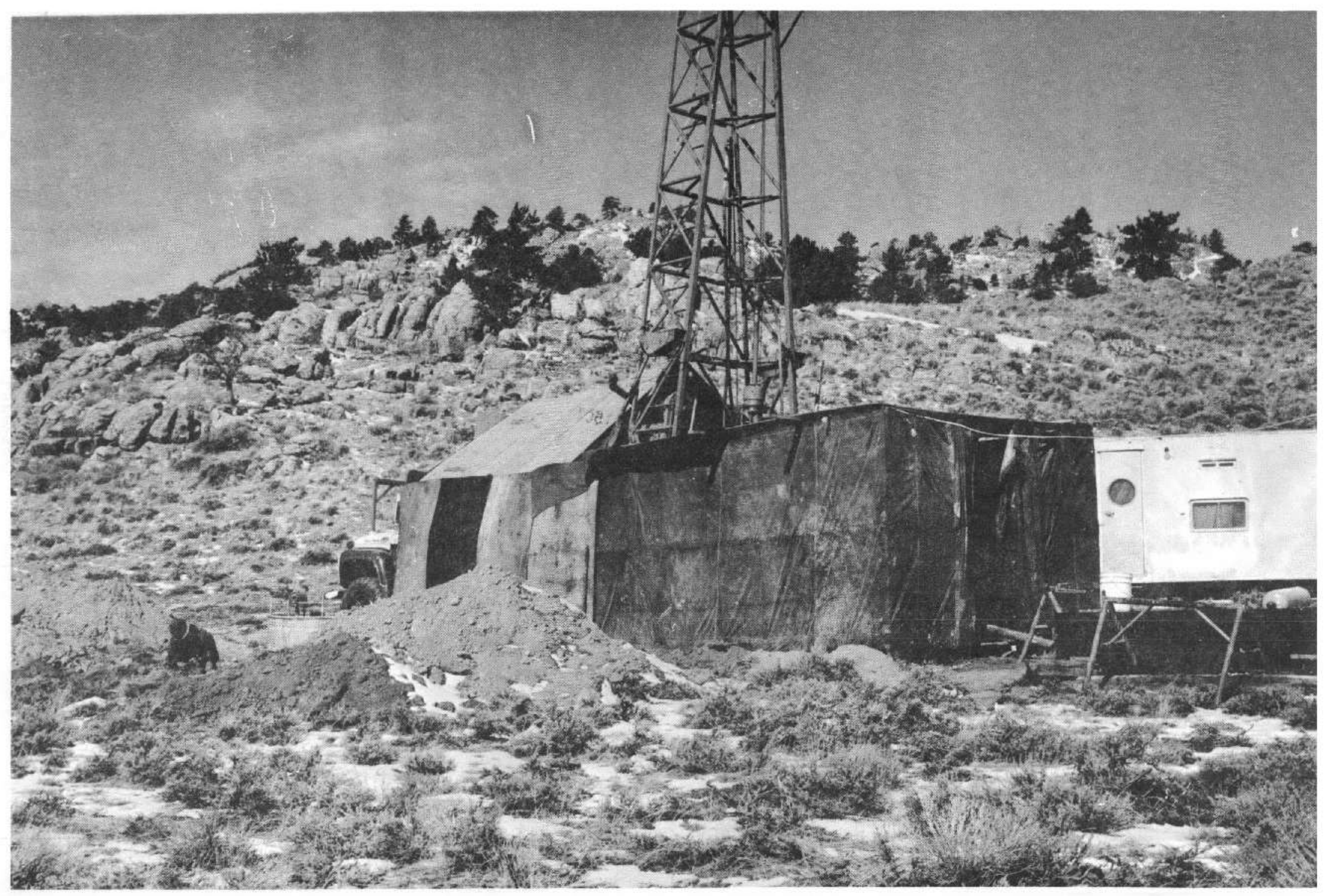

Figure 2. Drill rig on location. 
where a total loss occurred. Unsuccessful attempts were made to stop fluid loss by mixing wheat bran and drilling mud. Although circulation was lost, the core cuttings were carried out of the hole and into the fractured rock, thereby eliminating the possibility of a tight hole upon cessation of pumping. Progress was slowed by two fractured zones at 500 to $700 \mathrm{ft}$ and 1,300 to $1,600 \mathrm{ft}$. In these intervals, the intensely fractured rock frequently blocked the core barrel, causing very short core runs.

Due to unstable hole conditions, drill-rod torque gradually increased to the point that a twist-off situation was possible. To stabilize the hole and regain circulation, the HQ casing was reamed to $175 \mathrm{ft}$, and the hole was cemented from 1,200 to $1,520 \mathrm{ft}$. As a result, hole conditions were improved, but all drilling fluid still was lost. NQ coring continued to $1,924 \mathrm{ft}$, where loose gravel-size granite fragments were intercepted. These fragments did not remain in place after being cored and fragments tended to fall into the hole during the coring operation with sufficient pressure to severely score the outside of the core barrel. To ellminate this problem, the hole was cased through this zone with the NQ drill rod (2.375 in. I.D.).

\section{Third-Stage Cor1ng}

Following the setting of the NQ casing at 1,924 ft, the core size was reduced to $\mathrm{BQ}$ ( $1.43 \mathrm{in.}$ ) and coring continued to $1,936 \mathrm{ft}$. The hole was then reamed to the new depth and full circulation was regained. Coring was then resumed and continued without problems to $2,183 \mathrm{ft}$, where another altered zone was crossed. Here, the fractured granite deteriorated to rubble during drilling and made coring difficult. During this coring operation the hole was collapsing, which caused extreme drill-rod torque and excessive mudpump pressure. At 2,190 ft, a white, very fine-grained materlal, which consisted almost wholly of montmorillonite and quartz squeezed up the hole for 5 to $10 \mathrm{ft}$ when the drill rods were pulled for bit change. At 2,197 ft, no further progress could be made; therefore, the decision was made to abandon the hole.

\section{OTHER CONSIDERATIONS}

\section{Work Schedule}

Normal work schedule consisted of operating 24 hours per day, two shifts, for 10 days followed by 4 days break.

\section{Weather}

Temperature ranged from $0^{\circ}$ to $30^{\circ} \mathrm{F}$ during the first two weeks with winds of 10 to $20 \mathrm{mph}$. Snow flurries occurred periodically throughout the project. The coldest chill factor during the project was estimated at $-45^{\circ} \mathrm{F}$.

\section{Water Supply}

Water was purchased from the Bureau of Reclamation representing the North Platte River Project, actual owners of the water resources of the North Platte River drainage system. 
Dr. E. R. Decker, Associate Professor of Geology at the University of Wyoming, is performing a geothermal study. He requested the use of the core hole at completion of drilling and asked permission to install 1-1/4-1n. ptpe to the total depth for the purpose of taking temperature measurements during the next several months. His request to use the core hole and have the drilling subcontractor install the pipe was granted by Eugene W. Grutt, Jr., manager of ERDA, Grand Junction Office. The casing was cemented in place by Halliburton 011 We11 Cementing Co. The 4-in. surface casing was cemented in place, and a screw-on locking cap was installed.

\section{Completion}

Cleanup and rehabilitation of the drill site was completed on May 22. A. final inspection was made by the Bureau of Land Management May 24 and affirmative approval was given.

\section{SUMMARY OF CORE LITHOLOGY}

Immediately upon recovery, the core samples were studied and described. A preliminary description is presented below and summarized in Plate 1.

Drill hole PM-1 was collared in alluvium and intersected bed rock at a depth of $11 \mathrm{ft}(3.4 \mathrm{~m})$. From 11 to $121 \mathrm{ft}(3.4$ to $36.9 \mathrm{~m})$ core samples are dominantly chloritized and intensively fractured diabase. Some short intervals of pink to red, coarse-grained biotite granite were recovered with the diabase. From 122 to $141 \mathrm{ft}(36.9$ to $43.0 \mathrm{~m})$, the core samples consist of pink to red, strongly fractured biotite granite, similar to that recovered within the diabase. Both the red color and intense degree of fracturing of all granite recovered in the upper $141 \mathrm{ft}(43.0 \mathrm{~m})$ seem to be related to the intrusion or alteration of the diabase.

The character of the granite changes gradually in the interval 141 to $143 \mathrm{ft}(43.0$ to $43.6 \mathrm{~m})$. The color changes from red to light pink and light gray; it remains coarse grained, but fractures become rare. This 1ighter colored competent granite persists from 143 to $199 \mathrm{ft}(43.16$ to $60.17 \mathrm{~m})$. The amount of alteration of the granite increases again in the interval from 199 to $233 \mathrm{ft}(60.17$ to $71.0 \mathrm{~m})$, and most granite recovered in that interval is strongly fractured and stained with limontte. The general appearance is similar to weathered granite with brassy biotite.

From 223 to $363 \mathrm{ft}(71.0$ to $110.7 \mathrm{~m})$, the granite is generally $11 \mathrm{ght}$ pink to light gray in color, coarse grained, and only slightly fractured. Minor amounts of finer grained biotite granite and a few thin pegmatites were also recovered. Some narrow zones near the botton of this interval contain large (>1 cm) crystals of magnetite.

From 363 to $435 \mathrm{ft}$ ( 110.7 to $132.6 \mathrm{~m})$, core samples consist of mediumto coarse-grained chloritized dforite. Most core is intensely fractured and friable. Limonite staining is common. This dioritlc zone is transitional with the granite at the top and bottom and therefore is interpreted 
tentatively as a partly assimilated xenolith. From 435 to $524 \mathrm{ft}(132.6$ to $159.8 \mathrm{~m}$ ), the core samples are dominantly medium- to coarse-grained b1otite granite that ts only slightly fractured or altered. One section of the core from 450 to $452 \mathrm{ft}$ (137.2 to $137.8 \mathrm{~m}$ ) contains more than 50 percent magnetite. The interval from 524 to $611 \mathrm{ft}(159.8$ to $186.3 \mathrm{~m})$ consists of a mixture of strongly fractured diorite and granite. Chloritic alteration and limonite stalning are common throughout this interval.

Frotn 611 to $1,173 \mathrm{ft}$ ( 186.3 to $357.6 \mathrm{~m}$ ), the 11ght-pink to light-gray biotite granite is generally coarse gralned. In this interval, the granite consists of zones of moderately fractured fresh rock and zones of intensely fractured altered rock. Chlorite and biotite were noted in both zones, but chlorite is dominant in the closely fractured, limonite-stained samples. A few mafic segregations were recovered from this interval, and in some places the granite is somewhat pegmatitic. High concentrations of magnetite were also noted in a few pleces of core.

At $1,173 \mathrm{ft}(357.6 \mathrm{~m})$, the dril1 hole intersected a diabase dike at an angle of $10^{\circ}$. Core recovered to $1,566 \mathrm{ft}$ (477.4 m) consists of altered dlabase that is strongly fractured and chloritized. In a few places, the chloritized diabase contains small amounts of pyrite and ve1ns of calcite.

From 1,566 to $1,994 \mathrm{ft}(477.4$ to $607.9 \mathrm{~m})$, core samples generally are moderately fractured and consist of medium- to coarse-grained biotite granite that has minor chlorite and limonite stalning. A few thin, heavily fractured and altered zones were intersected in this interval, as well as a thin zone of mafic gneiss and a few thin granitic pegmatites. A biotite gneiss with some calcite veins was also recovered from the interval between 1,994 to $2,008 \mathrm{ft}(607.9$ to $612.2 \mathrm{~m})$.

Core samples recovered between 2,008 and $2,197 \mathrm{ft}(612.2$ to $669.8 \mathrm{~m})$ are strongly altered medium - to coarse-grained blotite granite. The alteration seems to be of two types, possibly having two distinct ages. Some samples have been albitized, which may represent alteration at the time of the intrusion. At the botton of the drill hole, most feldspar has been replaced by montmorillonite, which may have formed later in response to nearsurface conditions.

\section{DISCUSSTON}

At present it is not possible to assess how well the drilling of PM-1 meets the proposed goals of the project; however, several unforeseen benefits are now obvious. Two units, not found during surface work, were recovered in sufficient quantity to allow detalled geochemical and petrologic examination: montmorillonite-altered granite, and diorite inclustons in the granite. In addition, subsurface samples of diabase were not previously avallable for study.

The significance of the high-magnetite granite is unknown, but highmagnetite contents have been noted in the granite near the Little Man mine approximately 3 miles to the west. Anomalous magnetite content and associated slight uranfum enrichment were also noted in drill hole GM-1. Detailed studles of the magnet1te-bearing drill core from PM-1 may yield important clues for uranium exploration in other granitic terranes. 
It can be inferred from results of previous drilling and from the strong degree of alteration of the granite from PM-1 that the maximum depth of mobile urantum may not be found. From preliminary analyses, it can be deduced that several zones in PM-1 contain anomalous amounts of thorium and potassium. Analyses of these samples should supply information about uranium mobility in granites that have high radioelement contents.

From megascopic examination of the drill core, it seems likely that. much of it should be usable for identifying and evaluating the effect and extent of the postulated 1,600-m.y.-ago event. Furthermore if that event is related to the ubiquitous diabase dikes, the diabase core samples could provide valuable information.

This report is based on a preliminary examination of the cores. The U.S. Geological Survey will publish a more comprehensive report when all available analytical data have been recelved and evaluated.

\section{GEOPHYSICAL LOGGING}

As noted above, one objective of the project was collection of as much data as possible from the drill hole by using a variety of geophysical logging techniques. Both the U.S. Geological Survey and BFEC have logging capabilities, but neither is equipped to run the entire suite of logs deemed necessary for full evaluation. Accordingly, Birdwell was selected as subcontractor for the additional services. The following logs were run in the hole; most are illustrated as indicated.

\section{Birdwell Division, Selsmograph Service Corporation}

1. Directional Survey (P1. 2)

2. Gamma-Ray Neutron (P1. 3)

3. Density (P1. 4)

4. Temperature (PI. 5)

5. Three-Dimensional Velocity (P1. 6)

6. Electric (P1.7)

7. Caliper (P1. 8)

BFEC - Advanced Technology Division (ATD)

1. Resistivity

2. Caliper (P1. 9)

3. Spontaneous Potential 
4. Gross Gamma (P1, 9)

5. Neutron-Neutron (P1. 9)

6. Magnetic Susceptibllity (P1.9)

7. Spectral-Gamma (KUT) (Pl, 10)

USGS - Water Resources Group

1. Resistivity

2. Resistance

3. Temperature

4. Caliper

5. Gamma

6. Acoustic

7. Garma-Garma

8. Spontaneous Potentia1

9. Ep1thermal Neutron

USGS - Geophysica1 Group

1. Induced Polarization

EVALUATION OF GEOPHYSICAL LOGS

KUT (P1. 10)

The borehole was surveyed with a KUT (spectral-gamma) probe (P1. 10) from $1,490 \mathrm{ft}$ to the surface. Data were collected in the form of a digital. tape, which provided equivalent percent potassium $(\mathrm{K})$, ppm uranium $(U)$, and ppm thorium ( $\mathrm{T}$ ). An analog recording was also made of gross-gamma counts per second. (A 60-ft interval was recorded with a backup KUT probe for experimental purposes and is not included in this report).

As noted above, the diabase and grantte found in the borehole have a contrast in potassium content. The potassium (K) portion of the KUT log, when compared with the core discription provlded by the U.S. Geological Survey and Bendix, reflects this contrast. It can be discerned readily that granite has a relatively high potassium content and diabase a relatively low content. Near the top of the borehole from $10 \mathrm{ft}$ to $110 \mathrm{ft}$, the alternating diabase and grantte layers are graphically displayed on the potassium curve as alternating lows and highs. Farther down the borehole, from 378 to $398 \mathrm{ft}$, a diorite zone displays a very low potassium content as does the 
diabase zone from $1,173 \mathrm{ft}$ to $1,490 \mathrm{ft}$. The major granite zones, of course, produce the opposite response. It is evident that KUT logs offer considerable potential as a lithologic indicator in igneous rocks.

The thorium ( $T$ ) curve also contributes to lithologic identification in this $\log$. Upper diabase zones between $10 \mathrm{ft}$ and $110 \mathrm{ft}$ are depleted in thorium in contrast to the alternating granite zones. The diabase zone from $1,173 \mathrm{ft}$ to $1,409 \mathrm{ft}$ is also low in thorium, when compared to the thick granite zone lying just above it.

The uranium (U) portion of the KUT $10 \mathrm{~g}$ displays severa1 prominent zones of low uranium content, where uranium leaching could have occurred. These zones include $198-210 \mathrm{ft}, 218-225 \mathrm{ft}, 785-800 \mathrm{ft}, 810-823 \mathrm{ft}, 860-875 \mathrm{ft}$, 970$980 \mathrm{ft}$, and 1,025-1,050 ft. Al1 these zones occur in granite, and none are found in any other rock types. If it is assumed that the radioactive minerals were distributed somewhat homogeneously during emplacement or anatexis of the granite bodies, then these anomalously low uranfum values could represent leached areas. However, this determination cannot be made until radiometric and chemical analyses of the core are completed and made available. There is also a significant enrichment in uranium in the 1,175- to 1,200-ft interval, which probably represents addition of uranium to the diabase from the granite.

\section{Caliper (P1.9)}

The caliper $\log$ was run from $1,510 \mathrm{ft}$ to the surface and indicates borehole sizes ranging from $3.1 \mathrm{in.} \mathrm{to} 8.0 \mathrm{in}$. These data were used to provide borehole size corrections to the KUT $\mathrm{log}$, and in the future it will be used to correct other downhole logs. The N-N log is particularly susceptible to deviations in hole size. The caliper $\log$ is a good indicator of washedout zones that correlate with fractured zones described in the U.S. Geological Survey-Bendix core description.

\section{Neutron-Neutron $(\mathrm{N}-\mathrm{N}, \mathrm{P} 1,9)$}

Neutron-neutron data were collected from a depth of $1,502 \mathrm{ft}$ to the surface at $20 \mathrm{~K}$ cps maximum scale setting. When evaluating the $\mathrm{N}-\mathrm{N} \log$, it should be noted that the core description provided by U.S. Geological SurveyBendix mentions frequent and extensive fracturing of the rocks traversed by the borehole. Also, during the drilling process. circulation could not be maintained virtually from the outset. Because the $\mathrm{N}-\mathrm{N} \log$ responds primartly to the amount of hydrogen in a granite environment, it is a good indicator of the fractured zones where fluid losses resulted in lost circulation. In this regard, the N-N $\log$ corresponds very well with the caliper $\log$, which indicates fractured and washed-out sections of the borehole. In each place where the caliper shuws an increase in hole size, the $\mathrm{N}-\mathrm{N}$ shows a corresponding decrease in neutron counts.

\section{Magnetic Susceptibility (MS, Pl. 9)}

A magnetic susceptibility survey was logged from $1,502 \mathrm{ft}$ to the surface at a sensitivity of 267 micro-centimeter-gram-second ( $\mu \mathrm{cgs}$ ) units per Inch. 
No negative anomalies are shown on the 1 og but positive anomalies are abundant. The positive anomalies are substantiated by the U.S. Geological Survey-Bendix core description which cites the magnetic zones in detail. Because large amounts of lubricant were used during the core-drilling process, it is not likely that metal contamination is as much of a factor as it has been In past projects.

\section{Gamma-Electric}

A gamma-electric survey was run from $1,502 \mathrm{ft}$ to the surface. The gross-gamma portion of the log performed norma11y and provided data indicative of downhole condtions. However, because of the large amounts of lubricant (Black Magic) that were used during the core-driliing process, a highly resistive environment was artifically produced in the borehole. This effectively rendered the resistivity and spontaneous potential curves useless; therefore they are not included.

\section{Geophysical Inistrument Performance}

All downhole probes and associated electronic equipment performed admirably during the project and provided data indicative of downhole conditions. The only failure was the magnetic susceptibility probe provided by the U.S. Geological Survey.

\section{CONCLUSIONS}

Betore a definite conclusion can be drawn, it will be necessary to compare the geophysical data presented here with complete chemical and radiometric analysis of the core. If the evaluation of the KUT log corresponds with that analysis, the KUT $\log$ could be valuable in the evaluation of crystalline (granitic) rocks. Although analysts of the data still must be refined, the KUT $\log$ could provide a means for exploring granitic rocks for their potential as uranfum source rocks without core drilling. This could be accomplished by refining methods of 1ithologic determination using potassium and thorium curves and of identifying leached zones utilizing primarily the uranium curve.

The other logs run provided good amplifying information for the KUT $\log$. The magnetic-susceptility log indlcated the presence of magnetite, found only in the granite, thereby offering further 11thologic information. The caliper log shows deviations in hole size in possible fracture zones and will be used extensively in the future as a primary log to correct other logs for deviations in hole size. 

APPENDIX A. ADDITIONAL DRILLING DATA

A-1 
Additional information pertaining to the drilling operation in the Pedro Mountain No. 1 hole are presented below:

OPERATING TIME

46 days drilling and coring

7 days logging

22 days break

\section{AVERAGE BIT LIFE}

44.83 feet

\section{BITS USED}

$1-3-3 / 4$ in. tricone roller rock bit

2 - $\mathrm{HQ}$ diamond bits

38 - NQ diamond bits

9 - B? diamond bits

\section{TYPE AND SIZE BITS}

6-3/4 in. tricone roller rock bit

HQ (2.5 in. I.D. $x 3.78$ in. O.D.)

2 step

40 carats per bit

40 stones per carat

standard water course

NQ (1.875 in. I.D. $x 2.98$ in. O.D.)

5 step

25 carats per bit

60 stones per carat on the face 


\section{APPENDIX A. (continued)}

TYPE AND SIZE BITS (continued)

40 stones per carat on the step

standard water course

BQ (1.43 in. I.D. $x 2.36$ in. O.D.)

4 step

15 carats per bit

60 stones per carat on the face

40 stones per carat on the step

standard water course

\section{BIT PRESSURE}

$\mathrm{HQ}-2.5 \mathrm{lbs}$. to 5 lbs. per stone $(1,600$ stones/bit $)$

$\mathrm{NQ}-4 \mathrm{lbs}$. to 12.5 Ibs. per stone $(1,250$ stones/bit)

BO - 5 lbs. to 13.5 lbs. per stone (750 stones/b1t)

MUD PUMP PRESSURE

85 to 150 P.S.I.

REAMER SHELLS USED

$$
\begin{aligned}
& 1-H Q \\
& 2-N Q \\
& 1-B Q
\end{aligned}
$$

REAMER SHELL SIZES

$$
\begin{aligned}
\text { HQ }- & 16.5 \text { carats per reamer } \\
& 25 \text { stones per carat } \\
\mathrm{NQ}- & 11.5 \text { carats per reamer } \\
& 25 \text { stones per carat }
\end{aligned}
$$


APPENDIX A. (continued)

REAYER SHELI, SIZES (continued)

$B Q-7.5$ carats per reamer

30 stones per carat

CASINGS USED

$15.5 \mathrm{ft}, 4 \mathrm{in.} \mathrm{1.D.} \mathrm{(surface} \mathrm{pipe} \mathrm{cemented} \mathrm{in} \mathrm{place)}$

$175 \mathrm{ft} \mathrm{HW}$

$1936 \mathrm{ft} \mathrm{NQ}$

CASING SHOES USED

1 - HQ

$1-\mathrm{NQ}$

\section{CASING RECOVERED}

175 ft $\mathrm{HW}$

$1936 \mathrm{ft} N Q$

DRILLING MUD AND ADDITIVES

American Mud Products

Red Devil Gel

Mud Lub Drill Aid 405

Surf drill

Amvois (drill-rod lubricant)

Black Magic 
APPENDIX A. (continued)

CORING

\begin{tabular}{|c|c|c|c|c|}
\hline $\begin{array}{l}\text { Depth } \\
\text { (ft) }\end{array}$ & $\begin{array}{c}\text { Date } \\
(1976) \\
\end{array}$ & No. Core Runs & $\begin{array}{l}\text { Core Recovery } \\
(\%) \\
\end{array}$ & $\begin{array}{c}\text { Drift } \\
\text { (degrees) }\end{array}$ \\
\hline Start & $3 / 10$ & .. & $\cdots$ & $\cdots$ \\
\hline $0-100$ & $3 / 14$ & 29 & 95 & 1 \\
\hline $100-200$ & $3 / 15$ & 17 & 96 & 1.5 \\
\hline $200-300$ & $3 / 16$ & 16 & 94 & 1.5 \\
\hline $300-400$ & $3 / 17$ & 13 & 88 & 1.5 \\
\hline $400-500$ & $3 / 18$ & 19 & 89 & 2 \\
\hline 4-day break & $3 / 18-3 / 21$ & & & \\
\hline $500-600$ & $3 / 22$ & 26 & 94 & 2.5 \\
\hline $600-700$ & $3 / 25$ & 24 & 97 & 4 \\
\hline $700-800$ & $3 / 26$ & 18 & 95 & 4 \\
\hline $800-900$ & $3 / 27$ & 17 & 89 & 4.5 \\
\hline $900-1000$ & $3 / 28$ & 15 & 96 & 3.9 \\
\hline $1000-1100$ & $3 / 29$ & 17 & 95 & 4.5 \\
\hline $1100-1200$ & $3 / 30$ & 14 & 96 & 5.75 \\
\hline $1200-1300$ & $3 / 31$ & 20 & 98 & 5 \\
\hline 4-day break & $4 / 2-4 / 5$ & & & \\
\hline $1300-1400$ & $4 / 6$ & 25 & 98 & 5 \\
\hline $1400-1500$ & $4 / 8$ & 24 & 98 & 5.5 \\
\hline $1500-1600$ & $4 / 14$ & 33 & 95 & 5.5 \\
\hline 4-day break & $4 / 16-4 / 19$ & & & \\
\hline $1600-1700$ & $4 / 20$ & 24 & 91 & 6 \\
\hline $1700-1800$ & $4 / 21$ & 20 & 98 & 6 \\
\hline $1800-1900$ & $4 / 23$ & 18 & 97 & 7.5 \\
\hline
\end{tabular}


APPENDIX A. (continued)

\section{CORING (continued)}

\begin{tabular}{|c|c|c|c|c|}
\hline $\begin{array}{l}\text { Depth } \\
\text { (ft) } \\
\end{array}$ & $\begin{array}{c}\text { Date } \\
(1976) \\
\end{array}$ & No. Core Runs & $\begin{array}{c}\text { Core Recovery } \\
(\%)\end{array}$ & $\begin{array}{c}\text { Drift } \\
\text { (degrees) }\end{array}$ \\
\hline 5-day break & $4 / 26-4 / 30$ & & & \\
\hline $1900-2000$ & $5 / 2$ & 21 & 92 & 7.5 \\
\hline $2000-2100$ & $5 / 4$ & 21 & 95 & 8 \\
\hline $2100-2197$ & $5 / 7$ & 26 & 91 & \\
\hline Average & & & 94.4 & \\
\hline
\end{tabular}



